\title{
The Practicante: Puerto Rico Physician Assistant Prototype
}

\author{
Justine Strand, MPH, PA-C, Duke University Medical Center, \\ Durham, North Carolina
}

\section{INTRODUCTION}

Physician assistants (PAs) have achieved enabling legislation in all 50 states and almost all US territories, with the notable exception of Puerto Rico and American Samoa. (An attempt at passage of legislation authorizing PA practice in Puerto Rico was unsuccessful in 2000. ${ }^{1}$ ) Given that Puerto Rico is one of the last places in America to enact PA enabling legislation, it is surprising to learn that Puerto Rico had a PA prototype, the practicante, in the 19th and early 20 th centuries. The practicante was discontinued in 1931 when the Puerto Rican legislature passed a new law regulating the practice of medicine.

The Commonwealth of Puerto Rico is part of the Greater Antilles island chain in the Northwestern Caribbean. Christopher Columbus claimed the island for Spain in 1493, and it was under Spanish rule until it was ceded to the United States at the end of the Spanish American War in 1899. The island is 100 miles long and 35 miles across, and has 3,500 square miles of land and 750 miles of rugged coastline. A steep mountain range, the Cordillera Central, bisects the island from east to west. ${ }^{2}$ As recently as the second half of the 20 th century, Puerto Rico had many isolated areas that were difficult to reach because of a lack of roads. Trujillo-Pagan observes that in the 19 th and early 20 th centuries "... physicians rarely set foot in rural areas. They saw rural, interior mountainous regions as inaccessible
... these rural areas and the people who lived within them carried contagious diseases they felt ill-equipped to control." 3 Care of the poor in rural areas thus fell to another type of health care provider, who worked under the auspices of physicians-the practicante.

On May 29, 1866, the Royal Subdelegation of Medicine, which regulated the practice of medicine in Puerto Rico under the authority of the Spanish government, authorized the profession of practicante. ${ }^{4}$ The practicante is a forerunner to the modern PA. A two-volume manual for practicantes published in Spain in 1951 covers a broad range of medicine, including anatomy, physiology, diagnosis and treatment, suturing wounds, and setting fractures. ${ }^{5}$ Practicantes were typically located in rural and isolated areas, while licensed physicians usually practiced in more populous urban centers. Practicantes were classified as either minor or major, and surgical or medical, and the major practicantes had responsibility for supervision of those classified as minor. Practicantes' duties included bloodletting (accepted medical practice in the 19th century), pulling teeth, minor surgery, and care of the acutely ill.

Care of the sick was historically pluralistic in Puerto Rico, and was delivered by a variety of nonphysician and nontraditional practitioners, including comadronas and parteras (midwives), curanderos (folk healers), and curiosos (people who found medicine interesting and dabbled in it).

\section{PA HISTORY}

\begin{abstract}
Feature Editor's Note:
Feldshers, barefoot doctors, and frontier nurses are often cited as examples of prototypical physician assistants. But there is another, not previously mentioned in the literature-the practicante. Exported from Spain to Puerto Rico, the practicante was used to extend physician health care services in the commonwealth from the mid-1800s into the 1940 s. It is ironic that the last place in the US and its territories to enact enabling legislation for PAs was the first place in the Western hemisphere to legitimize and use a PA-like provider.
\end{abstract} - Reginald Carter, PhD, PA

Justine Strand can be reached at justine.strand@duke.edu

This feature publishes articles on all aspects of PA history. Much of the material comes from the PA History Center, which is dedicated to the study of the history and legacy of the physician assistant profession. Additional information can be found on the Society for the Preservation of Physician Assistant History at http:// pahx.org. Authors desiring to contribute to PA History should forward submissions to:

Reginald Carter, PhD, PA

Physician Assistant History Center

1121 Slater Road

Durham, NC 27703

Phone: 919-941-9325

Fax: 919-479-9726

Email:pahx@mc.duke.edu 
The role of the practicante was adopted from Spanish tradition, as were (obviously) many of the customs and practices in the Spanish-speaking new world. The practicante was supervised by a physician or surgeon (or in some cases by major practicantes), and occupied a position we would describe as "midlevel" today. Costa Mandry notes that "the profession of practicantes in Puerto Rico began as a consequence of the lack of physicians, the great number of patients under their [physicians'] care and the need for a person who could provide services urgently in [their absence]."6

A subtype of physician, called the municipal physician, was charged with caring for the poor in towns and villages and also had public health responsibilities for controlling epidemics and providing for vaccination of the populace. Each was aided, by edict, by five practicantes. ${ }^{7}$ Municipal physicians were loosely defined and may not have had formal medical training. (It should be noted that this was not unusual in those days; until Abraham Flexner's report on the scandalous state of American medical education in 1910, many mainland US physicians had for all practical purposes purchased their diplomas). Problems with access to care, combined with epidemics of cholera, bubonic plague, and the aftermaths of hurricanes, led to desperation on the part of government and the need to allow anyone who was willing to help to provide medical care. For example, curiosos and curanderos were authorized to vaccinate and prescribe in 1855, during a cholera epidemic. ${ }^{3}$ This set the stage for formalizing the role of the practicante through regulation by the Subdelegation of Medicine in 1866.

A beloved figure in Puerto Rican history of the mid-1800s, physician Ramón Emeterio Betances, utilized a practicante. Betances received his medical training in France and later became a leader in the Puerto Rican independence movement. He was exiled on several occasions because of his opposition to slavery and his political activism against Spanish authority. Though born into a wealthy family, he cared for the medically underserved; history documents his care for the poor people of Mayagüez during the cholera epidemic of 1855. On September 23, 1868, several hundred of his compatriots occupied the town of Lares, declared Puerto Rico independent, and set up a provisional government. The Spanish quelled this revolutionary spark, but the shouted motto of their revolution, "Puerto Rico Libre!" (Free Puerto Rico!) became known as the Grito de Lares (Cry of Lares) and remains the rallying cry for Puerto Rican independence. Betances' practicante, Juan B. Ventura, is listed in Spanish colonial regulatory records and noted in historical records as "el compañero de Betances (Betances's associate)."7

Arana-Soto provides documentation of the duties of the major practicante of surgery: "It is your obligation to treat the sick and injured as soon as they arrive at the Hospital, and if the [level of injury] requires it, involving the surgeon by notifying him of the diagnosis and treatment you have provided."7 The practicantes' manual speaks to role socialization: "In all your activities, obedience, respect and submission to the physician will be the basis of professional regard, but in no case should this become servility or adulation, because the only real servitude we all owe in our profession is to the sick." The manual goes on to assert: "The auxiliary mission requires a decided spirit of collaboration between physicians and their helpers for the benefit of the sick." 5
The practicante continued to exist after the US government took over regulation of medicine in 1899 but was eliminated in 1931 when the Puerto Rico legislature passed a new law regulating the practice of medicine and did not include practicantes. In 1945 a law establishing a role of "surgical technical auxiliary" (surgical technician) was created, which subsumed some aspects of the practicante's scope of practice. ${ }^{6}$ Despite their loss of legal status, some practicantes continued to provide health services, particularly in rural areas.

In 1942, when a proposal to expand training for public health in Puerto Rico was being debated, public health director Myron Wegman suggested that practicantes should undergo formal training through the new school. He wrote: "At present these men are looked down upon because of the inferior nature of their work. We must, however, recognize the actualities of the situation. They carry and will continue to carry a large part of the burden of medical care of the people. They are frequently criticized for practices beyond their ability but no attempt seems to be made to supervise or instruct them. Training would serve the double purpose of making them effective within their legitimate sphere of activity as well as making clear the danger of doing things for which they have no training."

Dr. Wegman's suggestion was not adopted, and the practicante remained without legal standing in Puerto Rico. ${ }^{8}$ The practicante has a place in history alongside Russia's feldshers and China's barefoot doctors. As Perry and Breitner noted in 1982: “The 'discovery' in the United States that appropriately trained nonphysicians are perfectly capable of diagnosing and treating common medical problems had been previously recog- 


\section{The Practicante: Puerto Rico Physician Assistant Prototype}

nized in both Russia and China." ${ }^{9}$ A similar discovery was made in Spain and exported to Puerto Rico, where the practicante was utilized extensively until legally discontinued in 1931. Perhaps it is time for history to come full circle and enable today's physician assistant to contribute to health care in the Commonwealth of Puerto Rico.

\section{ACKNOWLEDGEMENT}

The author would like to thank Nicole Trujillo-Pagan, PhD, for her assistance in the preparation of this article.

\section{REFERENCES}

1. Gardenhire R. American Academy of Physician Assistants. Letter to Sen. Kenneth McClintock, Request to sponsor enabling legislation for PAs in Puerto Rico in 2006 legislative session. 2005.

2. Peffer R. Puerto Rico. 2nd ed. Hawthorn, Vic: Lonely Planet Publications; 2002.

3. Trujillo-Pagan NE. Health beyond prescription: a post-colonial history of Puerto Rican medicine at the turn of the twentieth century. DAI. 2003;64(06A):298.

4. Costa-Mandry OG. Report on establishment of an accredited medical school at the University of Puerto Rico. Río Piedras, PR: University of Puerto Rico; 1944 .

5. Box María-Cospedal A. Manual teórico-práctico para practicantes, matronasy enfermeras. 3rd ed. Madrid: Instituto
Editorial Reus; 1951.

6. Costa Mandry O. Apuntes para la historia de la medicina en Puerto Rico: breve reseña histórica de las ciencias de la salud. San Juan, PR: Departamento de Salud, Estado Libre Asociado de Puerto Rico; 1971.

7. Arana-Soto S. Historia de la medicina puertorriquena hasta 1898. San Juan de Puerto Rico; 1974.

8. Ramirez de Arellano AB. Education for public health in Puerto Rico: 1940-1942. P R Health SciJ. Dec 1991;10(3):157-164.

9. Perry HB, Breitner B. Physician assistants: their contribution to health care. New York, NY: Human Sciences Press; 1982. 